Dept. of Food Control,

Fac. of Vet. Med., Kafr El-Sheikh University,

Kafr El-Sheikh 33516, Egypt.

\title{
DETECTION AND INACTIVATION OF ENTEROBACTER SAKAZAKII (CRONOBACTER) IN POWDERED INFANT MILK FORMULA
}

(With 5 Tables and 4 Figures)

\author{
By \\ AZZA M.M. DEEB
}

(Received at 15/9/2010)

\section{الكشف عن ميكروب الإنتيروباكتر ساكازاكى وإضعافه فى ألبان الأطفال الجافة \\ عزة مرغنسي محمد ديب}

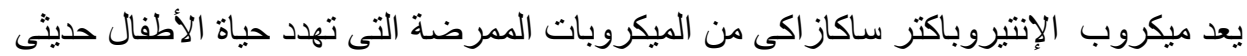

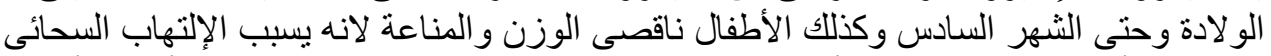

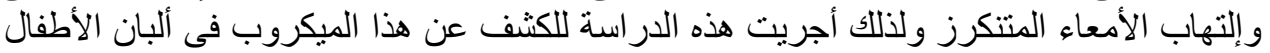

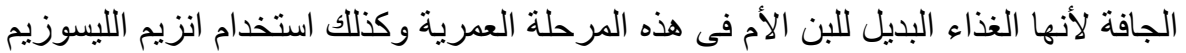

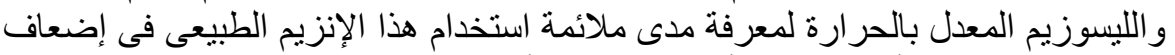

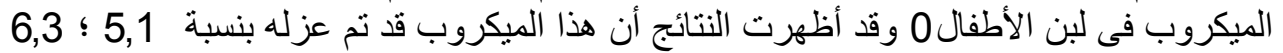

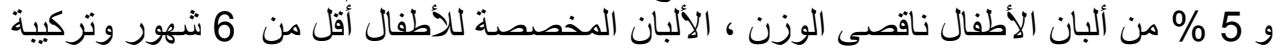

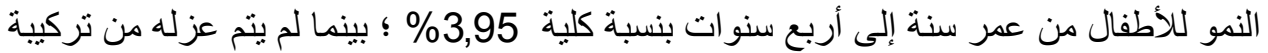

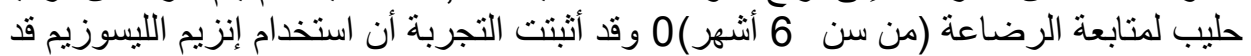

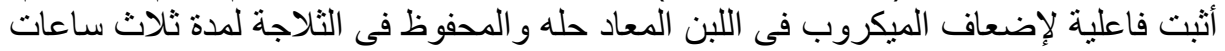

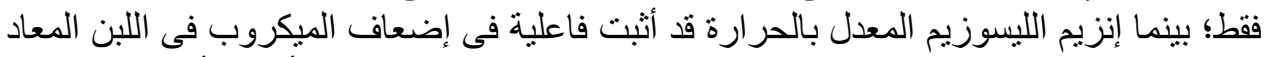

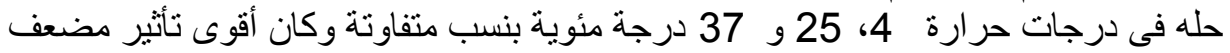

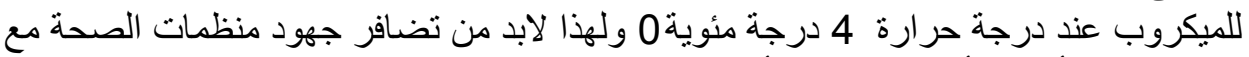

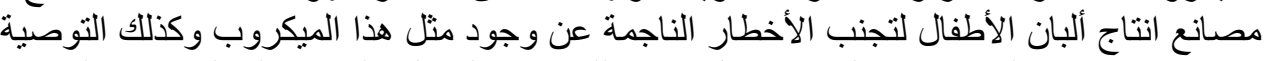

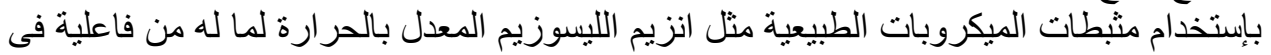
إضعاف ميكروب الإنتيروباكتر ساكاز اكى الميك

\section{SUMMARY}

E. sakazakii is considered as an opportunistic bacterium in elderly people and infants. Epidemiological studies implicate dried infant formula as the primary source of transmission of this pathogen. A total of 177 powdered infant milk formula (PIMF) [39 low birth weight formula from 1 day: 6 months (LBWF), 63 infant milk formula for infant below 6 months (IMF), 55 follow-on formula from 6:12 months and 20 growing children formula 
for age 1:4 years). The samples were collected from different pharmacies in Kafr El-Sheikh Governorate, Egypt, within the accurate shelf life period, and then transferred to the laboratory in their packages to be tested for detection of E. sakazakii and detection of the efficacy of Lysozyme and thermally modified lysozyme for inactivating E. sakazakii in reconstituted infant formula at different storage temperatures. The results revealed that E. sakazakii could be detected in 5.1, 6.3 and 5\% of examined LBWF, IMF and growing children formula respectively with total percentage of $3.95 \%$, but the organism could not be detected in follow-on formula. The results indicated that thermally modified lysozyme, was more effective than lysozyme in inhibition of E. sakasakii growth at $4{ }^{\circ} \mathrm{C}(\mathrm{p}<0.001)$, thermally modified lysozyme had more inhibitory effect on E. sakasakii at $4{ }^{\circ} \mathrm{C}$ than at 25 and $37^{\circ} \mathrm{C}$. In conclusion the combined efforts of public health and regulatory officials, as well as manufacturers, were considered important aspects of the management of risks associated with disease causing E. sakazakii in PIMF, also the uses of thermally modified lysozyme can exert a significant inhibitory activity against this organism in reconstituted milk formula specially when kept at refrigeration temperature.

Key words: Powdered infant milk formula, E. sakazakii, lysozyme, thermally modified lysozyme

\section{INTRODUCTION}

Powdered infant milk formula (PIMF) constitutes the majority of infant formula fed to infants' worldwide (Drudy et al., 2006). This product is formulated to mimic the nutritional profile of human breast milk (Breeuwer et al., 2003). PIMF is not a sterile product and can act as a potential source of harmful pathogens. In addition, infants and young children do not have a well developed immune system and hence are more vulnerable to food-borne infections. Therefore the microbiological safety of the infant and follow-up formula is critical. To assure the microbiological safety of PIMF, several microbiological tests are recommended and compared with the microbiological criteria set by the Codex Alimentarius Commission (CAC, 1979). The specific microbes commonly tested include Staphylococcus aureus, Bacillus cereus, Enterobacter sakazakii (E. sakasakii), other Enterobacteriaceae and Salmonellae (Forsythe, 2005). Among the specific microbes tested for presence in infant milk formula, E. sakazakii is placed under category A by FAO-WHO (FAO/WHO, 2004) and is considered to be a potential agent for causing neonatal infections. 
E. sakazakii, is a motile, non-sporeforming Gram-negative facultative anaerobe. It is considered as an opportunistic bacterium in elderly people and infants. While infections in adults are often underreported, in neonates and infants it is often occur as severe infection with a reported case fatality rate of $40-80 \%$ (Bowen and Braden, 2006). It is causing a rare, but life threatening form of neonatal meningitis, bacteremia, necrotizing colitis and meningo-encephalitis (Nazarowec-White and Farber, 1997a; Sanders and Sanders, 1997; Van Acker et al., 2001). In addition to the high fatality rate of E. sakazakii infections, it may result in severe neurological sequelae such as hydrocephalus, quadriplegia and retarded neural development in survivors (Forsythe, 2005). Although the environmental source of E. sakazakii is not clearly understood, epidemiological studies implicate PIMF as the primary source of transmission (Van Acker et al., 2001; Weir, 2002).

The bacterium has been isolated from PIMF by numerous investigators (Biering et al., 1989; Simmons et al., 1989; Muytjens and Kollee, 1990). Moreover; there were many recalls of E. sakazakiicontaminated infant formula in the United States. In November 2002, a nationwide recall of more than 1.5 million cans of dry infant formula contaminated with E. sakazakii was reported (FSNET, 2002). On April 12, 2002, the United States Food and Drug Administration (FDA) issued an alert to U.S. health care professionals regarding the risk associated with $E$. sakazakii infections among neonates fed PIMF (FDA, 2002). In addition, the International Commission on Microbiological Specification for Foods (ICMSF, 2002) has ranked E. sakazakii as 'Severe hazard for restricted populations, life-threatening or substantial chronic sequelae of long duration'. The FAO/WHO (2004; 2006 and 2008) recommended that research should be promoted to gain a better understanding of ecology, taxonomy, virulence and other characteristics of Cronobacter.

Being a nutrient-rich medium, reconstituted PIMF can support bacterial growth when favorable conditions of water availability, time and temperature are provided. Therefore once rehydrated the only limiting conditions for bacterial growth and infection are storage time and temperature. In this regard, E. sakazakii possesses several characteristics that enable it to be a successful infant formula-borne pathogen, Breeuwer et al. (2003) revealed that E. sakazakii has a high tolerance to osmotic stress and desiccation. E. sakazakii can grow at temperatures as low as $5.5^{\circ} \mathrm{C}$ (Nazarowec-White and Farber, 1997b), which has been reported to be the temperature of many home refrigerators. Improper storage of reconstituted formula may permit its substantial growth. Therefore, incorporation of an effective antimicrobial barrier may potentially reduce 
the likelihood of outbreaks of E. sakazakii infection in infants through ingestion of contaminated reconstituted infant formula.

In recent years, there has been an increasing interest in the use of natural antimicrobial substances due to concerns regarding the safety of synthetic compounds (Abee et al., 1995). This is especially significant when selecting antimicrobials for use in infant foods. Lysozyme is part of the innate immune system, however, reduced lysozyme levels have been associated with broncho-pulmonary dysplasia in newborns (Revenis and Kaliner, 1992). Children fed infant formula lacking lysozyme in their diet have three times the rate of diarrheal disease. Since lysozyme is a natural form of protection from pathogens like Salmonella, E.coli, and Pseudomonas, a deficiency due to infant formula feeding can lead to increased incidence of disease (Lonnerdal, 2003). Lysozyme found in egg white, tears, and other secretions. It is responsible for breaking down the polysaccharide walls of many kinds of bacteria thus it provides some protection against infection. Investigations conducted by Ibrahim et al. (1996) indicated a possibility of extending the range of lysozyme activity to include Gram-negative bacteria, using thermal modification. It has also been found that heat denaturation of lysozyme caused by increasing temperatures results in the progressive loss of enzymatic activity, while its antimicrobial action against Gram-negative bacteria is greatly enhanced.

The aim of this work was planned to detect E. sakazakii in PIMF and the efficacy of lysozyme and thermally modified lysozyme for inactivating E. sakazakii in reconstituted infant formula at different storage temperatures.

\section{MATERIALS and METHODS}

\section{Isolation and identification of E. sakazakii}

\subsection{Collection of samples}

One hundred and seventy seven PIMF [39 low birth weight formula from 1 day: 6 months (LBWF), 63 IMF for infant below 6 months, 55 follow-on formula from 6:12 months and 20 growing children formula for age 1:4 years). The samples were collected from different pharmacies in Kafr El-Sheikh Governorate, Egypt, within the accurate shelf life period, and then transferred to the laboratory in their packages to be tested for detection of E. sakazakii.

\subsection{Preparation of samples}

Twenty-five grams of each sample after sterilization and opening of the cans were homogenized for $1 \mathrm{~min}$ at medium speed in a Seward 
Stomacher (Seward, Thetford, UK) in $225 \mathrm{ml}$ buffered peptone-water (CM 509 Oxoid Ltd.) and incubated overnight at $37^{\circ} \mathrm{C}$ (ISO 8261, 2001).

\subsection{Isolation of $\boldsymbol{E}$. sakazakii procedure (ISO/TS 22964, 2006)}

To $10 \mathrm{ml}$ Cronobacter Screening Broth (CSB) (CM1121 Oxoid Ltd.) $0.1 \mathrm{ml}$ of pre-enrichment BPW was added and incubated at $41.5{ }^{\circ} \mathrm{C}$ for $24 \mathrm{~h}$. From yellow colored broth tube $10 \mu \mathrm{l}$ were streaked onto the surface of Brilliance Enterobacter sakazakii Agar (DFI) (CM 1055 Oxoid Ltd.) and colony morphology observed after incubation at $44^{\circ} \mathrm{C}$ for $24 \mathrm{~h}$. Blue green colonies were picked off and streaked on Tryptone soy agar (TSA) (CM131 Oxoid Ltd.). Colonies that produced yellow pigment after incubation at $25^{\circ} \mathrm{C}$ for $48-72 \mathrm{~h}$ were termed presumptive E. sakazakii.

\subsection{Identification of presumptive $E$. sakazakii}

Biochemical identification of presumptive E. sakazakii was done according to Farmer and Kelly (1992).

\section{Inactivation of $E$. sakazakii}

\subsection{Bacterial strain preparation}

E. sakazakii isolate was cultured in $10 \mathrm{ml}$ of sterile Tryptic soy broth (TSB) at $37^{\circ} \mathrm{C}$ for $20 \mathrm{~h}$. The bacterial population was determined by pour plate technique after preparation of serial dilutions according to APHA (1992). Loopfuls from each dilution were streaked on previously prepared TSA plate and then the plates were incubated at $37^{\circ} \mathrm{C}$ for $24 \mathrm{~h}$, the colonies forming unite / $\mathrm{ml}$ was calculated.

\subsection{Preparation of antimicrobials}

Egg white lysozyme (BioShop, Canada Inc.) stock solution of $1 \mathrm{mg} / \mathrm{ml}$ in potassium phosphate buffer $(10 \mathrm{mM}, \mathrm{pH} 7.0)$ was prepared (Barbara et al., 2000) and divided into two parts, one part was kept frozen at $-20{ }^{\circ} \mathrm{C}$ and the other part modified thermally by heating at $80{ }^{\circ} \mathrm{C}$ for 20 min ( Ibrahim et al., 1996).

\subsection{PIMF preparation}

PIMF was reconstituted as per the manufacturer's instructions on the label. Briefly, $135 \mathrm{~g}$ of the formula were reconstituted in $900 \mathrm{ml}$ of sterile distilled water; $100 \mathrm{ml}$ volumes were dispensed into screw capped bottles (9) and pasteurized at $63^{\circ} \mathrm{C}$ for $30 \mathrm{~min}$.

\subsection{Inoculation, incubation and determination of antibacterial activity}

To the bottles 2, 5 and 8 lysozyme solution was added, and to bottles 3,6 and 9 thermally modified lysozyme (denaturated) solution was added in final concentration $50 \mu \mathrm{g} / \mathrm{ml}(1000 \mathrm{U})$ of reconstituted IMF. Bottles 1 , of 4 and 7 were control (devoid of any antibacterial agent). E. sakazakii was added to the nine bottles in final count $2 \times 10^{6} / \mathrm{ml}$ of reconstituted IMF. 
Bottles 1, 2 and 3 were incubated at $4^{\circ} \mathrm{C}$, while bottles 4,5 and 6 were incubated at $25^{\circ} \mathrm{C}$ and bottles 7,8 and 9 were incubated at $37^{\circ} \mathrm{C}$ for $0,3,6$, 9,12 and $24 \mathrm{~h}$. The surviving populations of the pathogen were enumerated by plating after serial dilutions (1:10) on triplicate TSA after incubation at $37^{\circ} \mathrm{C}$ for $24 \mathrm{~h}$.

\section{Statistical analysis}

Data were analyzed using General Linear Models procedures after $\log$ transformation. Least square means were computed for each treatment and group differences were tested using Bonferroni test. All experiments and analyses were replicated 3 times (SAS Institute, 1999).

\section{RESULTS}

Table 1: Incidence of E. sakazakii in examined powdered infant milk formula.

\begin{tabular}{|c|c|c|c|}
\hline \multirow[t]{2}{*}{ Types of samples } & \multirow{2}{*}{$\begin{array}{c}\text { No. of } \\
\text { examined } \\
\text { samples }\end{array}$} & \multicolumn{2}{|c|}{$\begin{array}{c}\text { E. sakazakii positive } \\
\text { samples }\end{array}$} \\
\hline & & No & $\%$ \\
\hline Low birth weight formula & 39 & 2 & 5.1 \\
\hline PIMF for infant below 6 months & 63 & 4 & 6.3 \\
\hline Follow-on formula from $6: 12$ months & 55 & 0 & 0 \\
\hline Growing formula for age $1: 4$ years & 20 & 1 & 5 \\
\hline Total & 177 & 7 & 3.95 \\
\hline
\end{tabular}

Table 2: Effect of lysozyme and thermally modified lysozyme on E. sakazakii count incubated at $4^{\circ} \mathrm{C}$.

\begin{tabular}{|c|c|c|c|c|c|c|}
\hline \multirow{2}{*}{ Groups } & \multicolumn{5}{|c|}{ Mean log count \pm SE } \\
\cline { 2 - 7 } & $0^{*}$ & 3 & 6 & 9 & 12 & 24 \\
\hline Control & $14.26 \pm 0.15^{\mathrm{a}}$ & $14.41 \pm 0.32^{\mathrm{a}}$ & $17.12 \pm 0.56^{\mathrm{a}}$ & $18.32 \pm 0.32^{\mathrm{a}}$ & $19.17 \pm 0.17^{\mathrm{a}}$ & $20.02 \pm 0.11^{\mathrm{a}}$ \\
\hline \begin{tabular}{c} 
Lysozyme \\
\hline
\end{tabular} $13.60 \pm 0.51^{\mathrm{a}}$ & $11.74 \pm 0.46^{\mathrm{b}}$ & $13.73 \pm 0,26^{\mathrm{b}}$ & $14.12 \pm 0.31^{\mathrm{b}}$ & $15.40 \pm 0.17^{\mathrm{b}}$ & $16.52 \pm 0.07^{\mathrm{b}}$ \\
\hline $\begin{array}{c}\text { Thermally } \\
\text { modified } \\
\text { lysozyme }\end{array}$ & $13.76 \pm 0.43^{\mathrm{a}}$ & $2.95 \pm 0.37^{\mathrm{c}}$ & $5.90 \pm 0.32^{\mathrm{c}}$ & $6.58 \pm 0.65^{\mathrm{c}}$ & $9.08 \pm 0.39^{\mathrm{c}}$ & $11.51 \pm 0.06^{\mathrm{c}}$ \\
\hline
\end{tabular}

Means in the same column without a common letter differ significantly $(p<0.01)$.

*No significance difference $p=0.41$ 
Table 3: Effect of lysozyme and thermally modified lysozyme on E. sakazakii count incubated at $25^{\circ} \mathrm{C}$.

\begin{tabular}{|c|c|c|c|c|c|c|}
\hline \multirow{2}{*}{ Groups } & \multicolumn{5}{|c|}{ Mean log count \pm SE } \\
\cline { 2 - 7 } & $0^{*}$ & 3 & 6 & 9 & 12 & 24 \\
\hline Control & $14.11 \pm 0.62^{\mathrm{a}}$ & $15.91 \pm 0.51^{\mathrm{a}}$ & $17.70 \pm 0.43^{\mathrm{a}}$ & $20.00 \pm 0.025^{\mathrm{a}}$ & $24.93 \pm 0.15^{\mathrm{a}}$ & $28.27 \pm 0.38^{\mathrm{a}}$ \\
\hline \begin{tabular}{c} 
Lysozyme \\
\hline $\begin{array}{c}\text { Thermally } \\
\text { modified } \\
\text { lysozyme }\end{array}$
\end{tabular} & $13.41 \pm 1.10^{\mathrm{a}}$ & $16.00 \pm 0.34^{\mathrm{ab}}$ & $17.18 \pm 0.20^{\mathrm{ab}}$ & $18.37 \pm 0.05^{\mathrm{b}}$ & $20.49 \pm 0.46^{\mathrm{b}}$ & $25.23 \pm 0.32^{\mathrm{b}}$ \\
\hline
\end{tabular}

Means in the same column without a common letter differ significantly $(p<0.01)$.

*No significance difference $p=0.85$

Table 4: Effect of lysozyme and thermally modified lysozyme on E. sakazakii count incubated at $37^{\circ} \mathrm{C}$.

\begin{tabular}{|c|c|c|c|c|c|c|}
\hline \multirow{2}{*}{ Groups } & \multicolumn{5}{|c|}{ Mean log count \pm SE } \\
\cline { 2 - 7 } & $0^{*}$ & 3 & 6 & 9 & 12 & 24 \\
\hline Control & $14.06 \pm 0.63^{\mathrm{a}}$ & $16.65 \pm 1.13^{\mathrm{a}}$ & $18.13 \pm 0.55^{\mathrm{a}}$ & $20.03 \pm 1.01^{\mathrm{a}}$ & $23.85 \pm 1.60^{\mathrm{a}}$ & $29.71 \pm 0.07^{\mathrm{a}}$ \\
\hline Lysozyme & $13.29 \pm 0.89^{\mathrm{a}}$ & $17.06 \pm 0.63^{\mathrm{ab}}$ & $17.99 \pm 0,63^{\mathrm{ab}}$ & $18.71 \pm 0.41^{\mathrm{ab}}$ & $22.59 \pm 0.63^{\mathrm{ab}}$ & $27.34 \pm 0.55^{\mathrm{b}}$ \\
\hline $\begin{array}{c}\text { Thermally } \\
\text { modified } \\
\text { lysozyme }\end{array}$ & $13.34 \pm 0.99^{\mathrm{a}}$ & $11.65 \pm 0.52^{\mathrm{c}}$ & $13.45 \pm 0.37^{\mathrm{c}}$ & $13.95 \pm 0.52^{\mathrm{c}}$ & $18.18 \pm 0.15^{\mathrm{b}}$ & $22.81 \pm 0.33^{\mathrm{c}}$ \\
\hline
\end{tabular}

Means in the same column without a common letter differ significantly $(p<0.01)$.

*No significance difference $p=0.78$

Table 5: Effect of lysozyme and thermally modified lysozyme on E. sakazakii count at different incubation temperature throughout the experiment.

\begin{tabular}{|c|c|c|c|}
\hline \multirow{2}{*}{ Groups } & \multicolumn{3}{|c|}{ Mean log count \pm SE } \\
\cline { 2 - 4 } & $4^{\mathrm{o}} \mathrm{C}$ & $25^{\mathrm{o}} \mathrm{C}$ & $37^{\mathrm{o}} \mathrm{C}$ \\
\hline Lysozyme & $14.19 \pm 0.38^{\mathrm{a}}$ & $18.45 \pm 0.92^{\mathrm{c}}$ & $19.50 \pm 1.10^{\mathrm{c}}$ \\
\hline $\begin{array}{c}\text { Thermally modified } \\
\text { lysozyme }\end{array}$ & $8.30 \pm 0.88^{\mathrm{b}}$ & $14.99 \pm 1.05^{\mathrm{d}}$ & $15.56 \pm 0.94^{\mathrm{ed}}$ \\
\hline
\end{tabular}

Means in the same column without a common letter differ significantly $(p=0.03)$.

Means in the same row without a common letter differ significantly $(p=0.02)$. 
Fig. 1: Effect of lysozyme and thermally modified lysozyme on E.sakasakii count incubated at $4^{\circ} \mathrm{C}$.

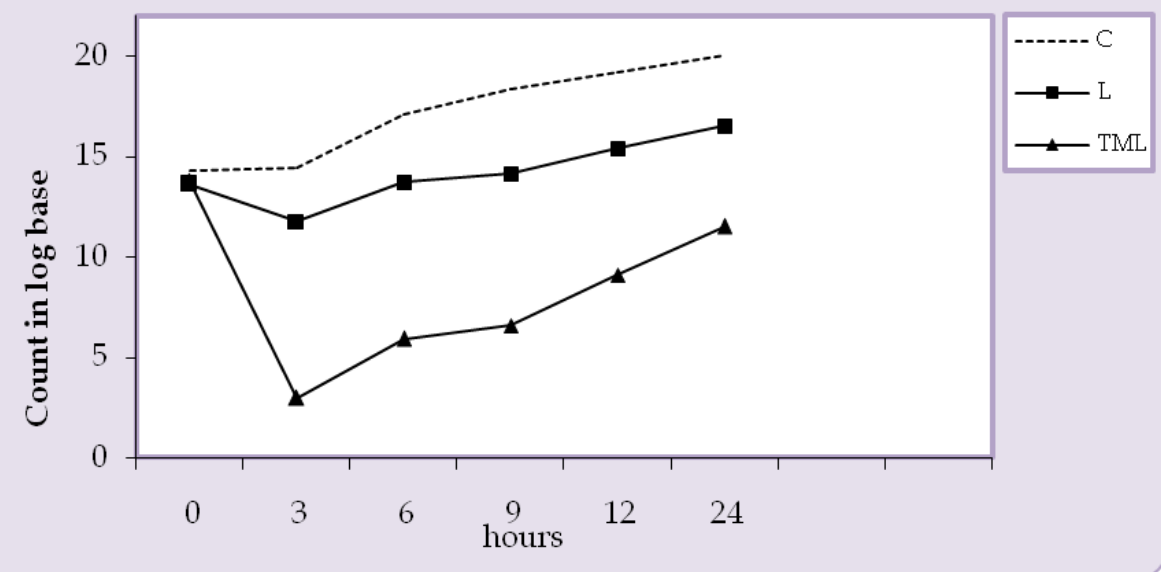

C: control

L: Lysozyme

TML: Thermally modified lysozyme

Fig. 2: Effect of lysozyme and thermally modified lysozyme on

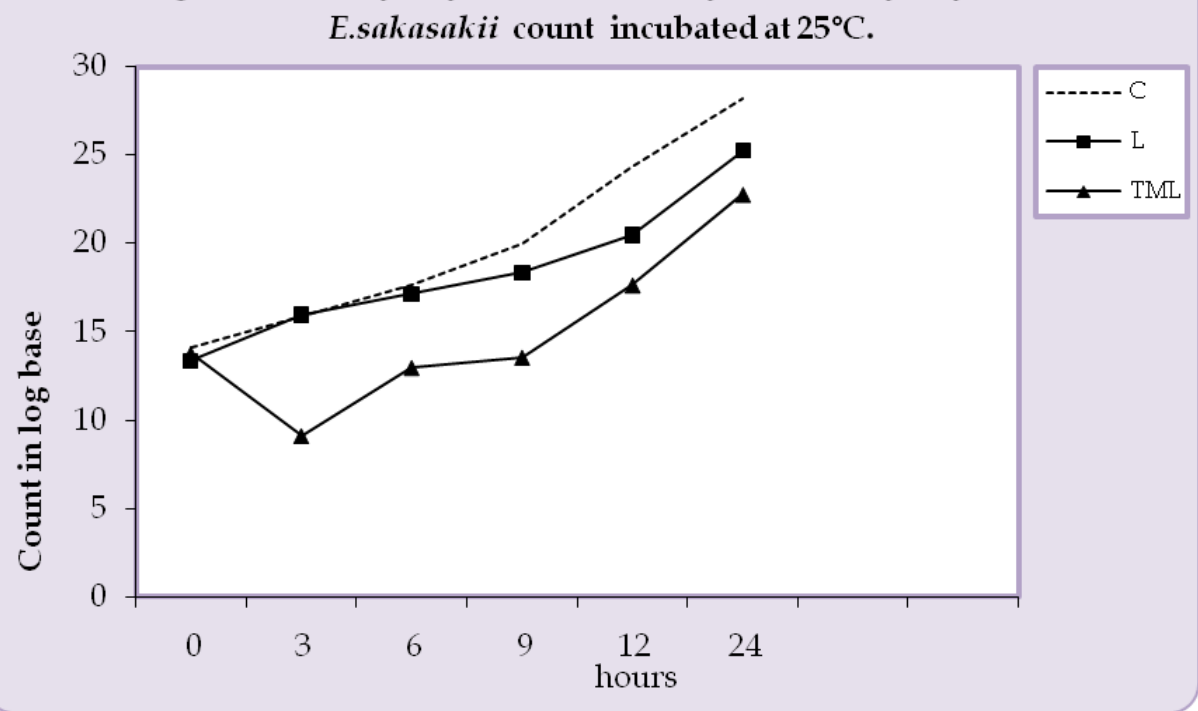


Fig. 3: Effect of lysozyme and thermally modified lysozyme on E.sakasakii count incubated at $37^{\circ} \mathrm{C}$.

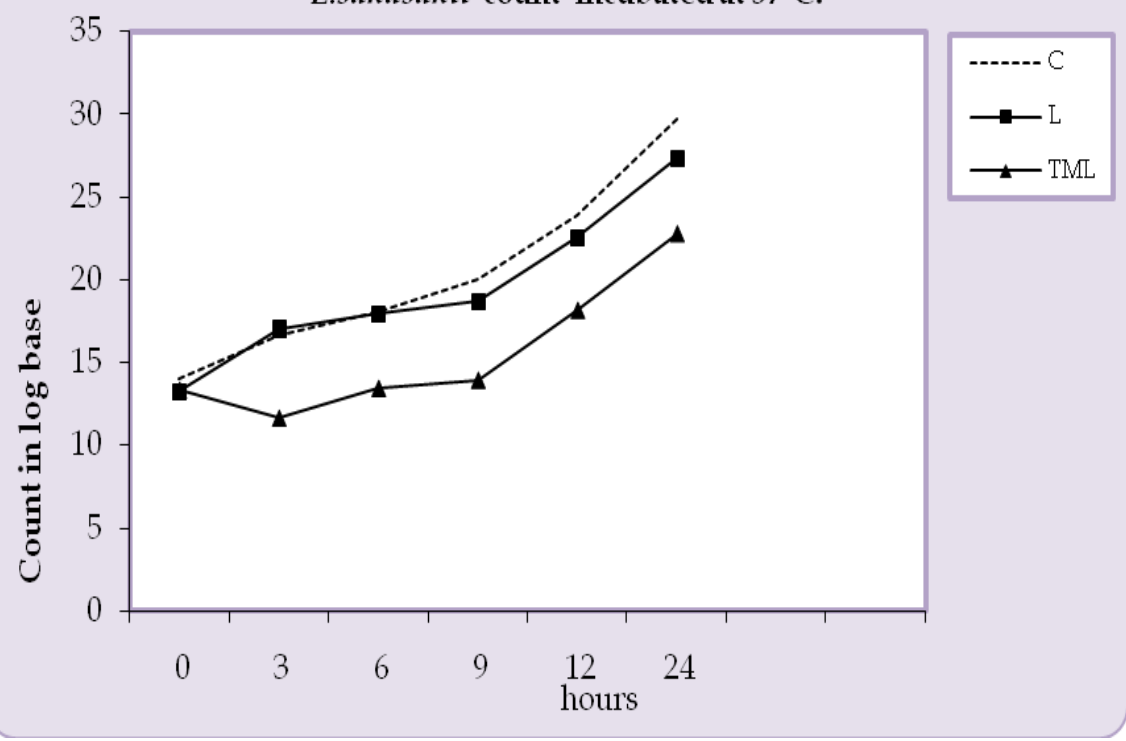

Fig. 4: Effect of lysozyme and thermally modified lysozyme on E. sakasakii count at differentincubation temperature throughout the experiment

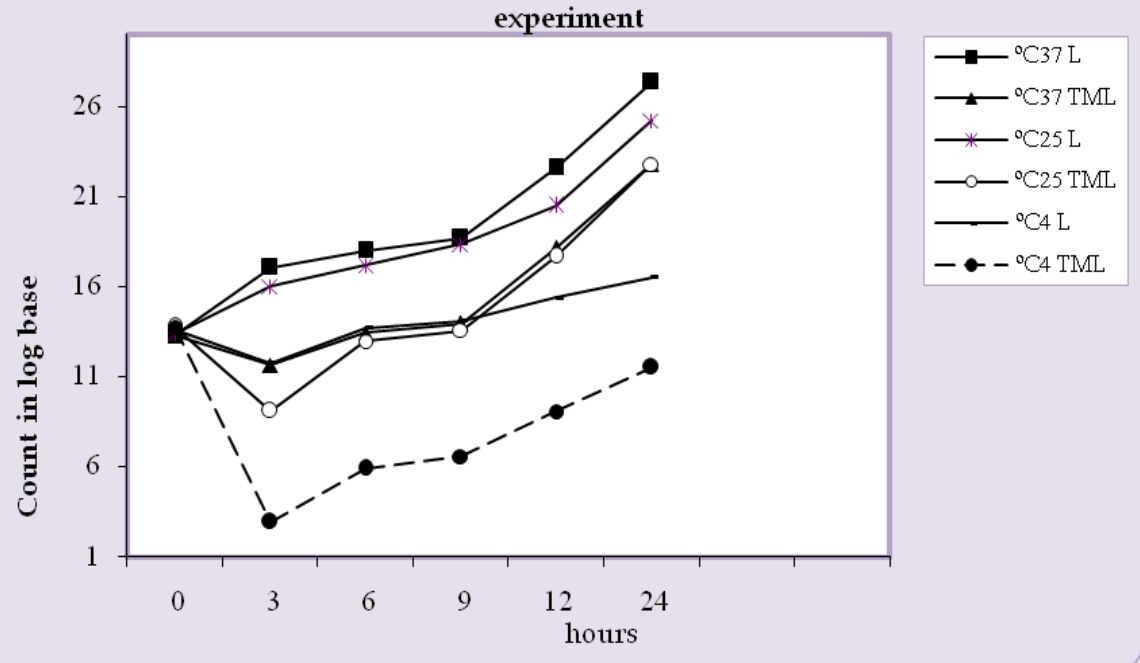




\section{DISCUSSION}

In Europe and the United State, several studies have reported cases of E. sakazakii infection in infants taking a PIMF, raising an important issue. This study was focused on PIMF in response to the FAO/WHO (2008) call for appropriate microbiological data. Results given in Table 1 pointed out that the rate of contamination with E. sakazakii was 5.1, 6.3 and 5\% of the examined LBWF, IMF (for age $<6$ months) and growing formula, respectively with a total percentage of $3.95 \%$, while the organisms could not be detected in follow-on formula. Concerning prevalence in powdered formulae, some reported prevalence figures in positive batches were about 1 and 3\% (FAO/WHO, 2008), and nearly similar results were reported by Yoo et al. (2005); Chap et al. (2009) and Oonaka et al. (2010). Presence of E. sakazakii in PIMF may be attributed to inadequate hygiene in factory or contamination of raw materials.

Cronobacter spp. infections have been reported for all age groups. Worldwide there have been 120 reported cases in infants and children $<3$ years in age, of which 8 were cases aged between 6 and 35 months. In the UK between 1999 and 2007, 15/570 laboratory reported infections were from infants $(<12$ months in age), and 16/570 were from children (14 years in age) (FAO/WHO, 2008). Risk for infection might depend on several factors, including the number of bacteria present in the product, handling after preparation, and underlying patient characteristics (e.g., immune-suppression, prematurity, or low birth weight). Because powdered formula is not sterile and can provide a good medium for growth, prolonged periods of storage or administration at room temperature might amplify the amount of bacteria already present.

FDA (2002) recommended that powdered infant formulas not be used in neonatal intensive care settings unless there is no alternative available. If the only option available to address the nutritional needs of a particular infant is a powdered formula, risks of infection can be reduced by preparing only a small amount of reconstituted formula for each feeding to reduce the quantity and time that formula is held at room temperature for consumption; minimizing the holding time, whether at room temperature or while under refrigeration, before a reconstituted formula is fed; and minimizing the "hang-time" (i.e., the amount of time a formula is at room temperature in the feeding bag and accompanying lines during enteral tube feeding), with no "hang-time" exceeding 4 hours. Longer times should be avoided because of the potential for significant microbial growth in reconstituted infant formula. 
Natural antimicrobials have gained attention because of the demand for preservative-free food products (Payne et al., 1990). Included as natural antimicrobial is lysozyme enzymes that can inhibit the growth of various intestinal pathogens and which can protect children against gastroenteritis (Lonnerdal, 2003).

The growth of E. sakazakii was evaluated after treatment with lysozyme and thermally modified lysozyme in reconstituted milk formula and incubated at 4,25 and $37{ }^{\circ} \mathrm{C}$. The Effect of lysozyme and thermally modified lysozyme on E. sakasakii count in reconstituted milk formula incubated at $4^{\circ} \mathrm{C}$ throughout the experiment was presented in Table 2 and Figure 1. The results declared that there was no significant difference between control, lysozyme and thermally modified lysozyme treated samples at zero time $(p=0.41)$, while there were significant difference between the three treatments from $3 \mathrm{~h}$ to $24 \mathrm{~h}(p<0.01)$, at $3 \mathrm{~h}$ of incubation the population of $E$. sakazakii was reduced to $11.74 \pm 0.46 \mathrm{log}$ base $\mathrm{CFU} / \mathrm{ml}$ by lysozyme and to $2.95 \pm 0.37 \mathrm{log}$ base CFU/ml by thermally modified lysozyme. At the end of the $24 \mathrm{~h}$, the count of E. sakasakii in the sample containing lysozyme reached to $16.52 \pm 0.07 \log$ base $\mathrm{CFU} / \mathrm{ml}$ which is 1.2 times than the initial count whereas that containing thermally modified lysozyme had $11.51 \pm 0.06 \mathrm{log}$ base $\mathrm{CFU} / \mathrm{ml}$ which is less than the initial count $(13.76 \pm 0.43 \log$ base $\mathrm{CFU} / \mathrm{ml})$. In the control sample devoid of neither lysozyme nor thermally modified lysozyme, the pathogen grew, reaching a final population of $20.02 \pm 0.11 \log$ base $\mathrm{CFU} / \mathrm{ml}$. These results indicate that thermally modified lysozyme, was more effective than lysozyme in inhibition of $E$. sakazakii growth at $4{ }^{\circ} \mathrm{C}(p<0.001)$.

Table 3 and Figure 2 show the effect of lysozyme and thermally modified lysozyme on E. sakasakii count in reconstituted milk formula incubated at $25^{\circ} \mathrm{C}$ throughout the experiment and revealed that there was significant difference between lysozyme and thermally modified lysozyme treated samples $(p<0.01)$, lysozyme had no antibacterial effect on E. sakazakii throughout the experiment. While at $3 \mathrm{~h}$ and $6 \mathrm{~h}$ thermally modified lysozyme reduced the pathogen count by $9.11 \pm 0.32$ and $12.99 \pm 0.07 \log$ base $\mathrm{CFU} / \mathrm{ml}$. At $9 \mathrm{~h}$ of incubation the count reach approximately the initial count $(13.57 \pm 0.15 \log$ base CFU/ml), at $24 \mathrm{~h}$ of incubation the count reached $22.81 \pm 0.06 \log$ base $\mathrm{CFU} / \mathrm{ml}$ which is 1.7 times than the original count. In the control sample devoid of neither lysozyme nor thermally modified lysozyme, the pathogen grew, reaching a final population of $28.27 \pm 0.38 \log$ base $\mathrm{CFU} / \mathrm{ml}$. These results indicate that 
thermally modified lysozyme, was effective in inhibition of E. sakazakii growth at $25^{\circ} \mathrm{C}$ till $6 \mathrm{~h}$ of storage.

The Effect of lysozyme and thermally modified lysozyme on E. sakazakii count in reconstituted milk formula incubated at $37^{\circ} \mathrm{C}$ throughout the experiment is presented in Table 4 and Figure 3 and revealed that there was significant difference between lysozyme and thermally modified lysozyme treated samples $(p<0.01)$, lysozyme had no antibacterial effect on E. sakazakii throughout the experiment. While at $3 \mathrm{~h}$ thermally modified lysozyme reduced the pathogen count by $11.65 \pm 0.52$ $\log$ base CFU/ml. At $6 \mathrm{~h}$ of incubation the count reach approximately the initial count $(13.45 \pm 0.37 \log$ base $\mathrm{CFU} / \mathrm{ml})$, at $24 \mathrm{~h}$ of incubation the count reached $22.81 \pm 0.33 \log$ base $\mathrm{CFU} / \mathrm{ml}$ which is 1.7 times than the original count. In the control sample devoid of neither lysozyme nor thermally modified lysozyme, the pathogen grew, reaching a final population of $29.71 \pm 0.07 \log$ base $\mathrm{CFU} / \mathrm{ml}$. These results indicate that thermally modified lysozyme, was effective in inhibition of E. sakazakii growth at $37^{\circ} \mathrm{C}$ till $3 \mathrm{~h}$ of storage.

There were significant differences between lysozyme and thermally modified lysozyme treated samples at different incubation temperatures $(p<0.03)$. There were significant differences between lysozyme treated samples incubated at $4{ }^{\circ} \mathrm{C}$ and lysozyme treated samples incubated at both 25 and $37^{\circ} \mathrm{C}$, also there were significant differences between thermally modified lysozyme treated samples incubated at $4{ }^{\circ} \mathrm{C}$ and thermally modified lysozyme treated samples incubated at both 25 and $37{ }^{\circ} \mathrm{C}$ (Table 5 and Figure 4). The results indicated that the thermally modified lysozyme had more inhibitory effect on E. sakazakii at $4{ }^{\circ} \mathrm{C}$ than at 25 and $37^{\circ} \mathrm{C}$.

Heat denaturation of lysozyme resulted in the progressive loss of enzymatic activity, but a greatly improved antimicrobial action towards Gram-negative bacteria through membrane perturbation (Ibrahim, 1998). The possibility to extend the range of lysozyme activity to include Gramnegative bacteria i.e. E. coli, is offered by the thermal and chemicalthermal modification, which leads to the formation of an enzyme preparation with increased content of polymeric forms (Lesnierowski et al., 2004).

The antimicrobial action of lysozyme was due to structural factors. Specific bactericidal domain may be involved in the antimicrobial action of lysozyme (Düring et al., 1999; Ibrahim, 1998 and Ibrahim, 2003). 
The inhibitory effect of thermally modified lysozyme on $E$. sakazakii at $4{ }^{\circ} \mathrm{C}$ was more than at 25 and $37{ }^{\circ} \mathrm{C}$ this may be attributed to the long generation time of the pathogen at refrigeration temperature $(4.98 \mathrm{~h})$ than at room temperature (40 min.) and at $37{ }^{\circ} \mathrm{C}(24 \mathrm{~min}$ ) (Nazarowec-White and Farber, 1997a; Pagotto and Farber, 2009).

The results of this study indicate that despite the fact that formulas are exposed to heat treatment during processing E. sakazakii was still isolated from these products. The combined efforts of public health and regulatory officials, as well as manufacturers, were considered important aspects of the management of risks associated with disease causing E. sakazakii in PIMF, also the uses of thermally modified lysozyme can exert a significant inhibitory activity against this organism in reconstituted milk formula specially when kept at refrigeration temperature.

\section{REFERENCES}

Abee, T.; Krockel, L. and Hill, C. (1995): Bacteriocins: modes of action and potentials in food preservation and control of food poisoning. Int. J. Food Microbiol., 28: 169-185.

APHA "American Public Health Association" (1992): Standard Methods for Examination of Dairy Products, $16^{\text {th }}$ ed, American Public Health Association, Washington, DC.

Barbara, M.; Cristina, G.G.; Ellen, V.H. and Chris, W.M. (2000): Inactivation of high pressure resistant E.coli by lysozyme and nisin under high pressure. Innovation Food Sci. Technologies, 1: 39-47.

Biering, G.; Karlsson, S.; Clark, N.C.; Jonsdottir, K.E.; Ludvigsson, P. and Steingrimsson, O. (1989): Three cases of neonatal meningitis caused by E. sakazakii in powdered milk. J. Clinical Microbiol., 27: 2054-2056.

Bowen, A. and Braden, C. (2006): Invasive E. sakazakii disease among infants. Emerging Infectious Diseases, 12(8): 1185-1189.

Breeuwer, P.; Lardeau, A.; Peterz, M. and Joosten, H.M. (2003): Desiccation and heat tolerance of E. sakazakii. J. Appl. Microbiol., 95: 967-973.

CAC "Codex Alimentarius Commission" (1979): Recommended international code of hygienic practice for foods for infants and children (CAC/ RCP 21-1979). Accessed on May 10, 2008 at: ftp://ftp.fao.org/ codex/standard/en/CXP_021e.pdf. 
Chap, J.; Jackson, P.; Siqueira, R.; Gaspar, N.; Quintas, C.; Park, J.; Osaili, T.; Shaker, R.; Jaradat, Z.; Hartantyo, S.H.P.; Abdullah Sani, N.; Estuningsih, S. and Forsythe, S.J. (2009): International survey of Cronobacter sakazakii and other Cronobacter spp. in follow up formulas and infant foods. Int. J. Food Microbiol., 136 (2): 185-188.

Drudy, D.; Mullane, N.R.; Quinn, T.; Wall, P.G. and Fanning, S. (2006):

E. sakazakii: an emerging pathogen in powdered infant formula. Clinical Infectious Diseases, 42: 996-1002.

Düring, K.; Porsch, P.; Mahn, A.; Brinkmann, O. and Gieffers, W. (1999): The non-enzymatic microbicidal activity of lysozyme. FEBS Lett., 449: 93-100.

FAO/WHO "Food and Agriculture Organization/World Health Organization" (2004): E. sakazakii and other microorganisms in powdered infant formula. Microbiol., Assessment Series No. 6, Italy.

FAO/WHO "Food and Agriculture Organization/World Health Organization" (2006): E. sakazakii and Salmonella in powdered infant formula: Meeting report. Microbiological Risk Assessment Series, No. 10. 95p. Rome, Italy. Also available at: $\mathrm{ftp}: / / \mathrm{ftp}$.fao.org/docrep/fao/007/y5502e/y5502e00.pdf.

FAO/WHO "Food and Agriculture Organization/World Health Organization" (2008): Enterobacter sakazakii (Cronobacter spp.) in powdered follow-up formulae. MRA series (2008) Available at http://www.who.int/foodsafety/publications/micro/MRA_followu p.pdf. Date last accessed 03/09/09.

Farmer, J.J. and Kelly, M.T. (1992): Enterobacteriaceae. Manual Clinical Microbiol., 360-383.

FDA "Food and Drug Administration" (2002): FDA warns about possible E. sakazakii infections in hospitalized newborns fed powdered infant formulas. FDA Talk Paper, April 12, 2002. Accessed on May 25, 2008 at http://www.fda.gov/bbs/topics/ ANSWERS/2002/ANS01146.html.

Forsythe, S.J. (2005): E. sakazakii and other bacteria in powdered infant formula. Maternal and Child Nutrition, 1: 44-50.

FSNET (2002): Recalled baby formula found in Colorado Stores. November 6, 2002. Colorado Department of Public Health and Environment Press Release. Accessed on May 9, 2008 at: http://131.104.232.9/fsnet/11-2002/. 
Ibrahim, H.R.; Higashiguch, I.S.; Juneja, L.R.; Kim, M. and Yamamoto, T. (1996): A structural phase of heat-denatured lysozyme with novel antimicrobial action. J. Agric. Food Chem., 44: 1416-1423.

Ibrahim, H.R. (1998): On the novel catalytically-independent antimicrobial function of hen egg-white lysozyme: A conformation-dependent activity. Nahrung, 42: 187-193.

Ibrahim, H.R. (2003): Hen egg white lysozyme and ovotransferrin: mystery, structural role and antimicrobial function. In: Proceedings of the Xth European Symposium on the Quality of Eggs and Egg Products (Nys, Y. Ed.). Saint-Brieuc, France, pp.: 350-365.

ICMSF "International Commission on Microbiological Safety of Food" (2002): Microorganisms in foods 7. Microbiological testing in food safety management. Kluwer Academic/ Plenum Publishers.

ISO 8261"International Organization for Standardization" (2001): Milk and milk products- General guidance for the preparation of test samples initial suspensions and decimal dilutions for micobiological examination.

ISO/TS 22964" International Organization for Standardization" (2006): Milk and milk products-detection of E. sakazakii. Technical specification. ISO/TS 22964:2006 (E) and IDF/RM 210:2006(E), 1 st ed., Geneva, Switzerland

Lesnierowski, G.; Cegielska-Radziejewska, R. and Kijowski, J. (2004): Thermally and chemical thermally modified lysozyme and its bacteriostatic activity. World's Poultry Sci J., 60: 303-309.

Lonnerdal, B. (2003): Nutritional and physiologic significance of human milk proteins. Am. J. Clin. Nutr., 77 (6): 1537S-1543S.

Muytjens, H.L. and Kollee, L.A. (1990): E. sakazakii meningitis in neonates: causative role of formula?. Pediatric Infectious Diseases J., 9: 372-373.

Nazarowec-White, M. and Farber, J.M.(1997a): E. sakazakii: a review. Int. J. Food Microbiol., 34: 103-113.

Nazarowec-White, M. and Farber, J.M. (1997b): Thermal resistance of E. sakazakii in reconstituted dried-infant formula. Letters in Appl. Microbiol., 24: 9-13.

Oonaka, K.; Furuhata, K.; Hara, M. and Fukuyama, M. (2010): Powder infant milk contamination with E. sakazakii. Jpn. J. Infect. Dis., 63: 103-107.

Pagotto, F.J. and Farber, J.M. (2009): Coronobacter spp. (E. sakazakii): Advice, policy and research in Canada. Int. J. Food Microbiol., 136: 238-245. 
Payne, K.D.; Davidson, P.M.; Oliver, S.P. and Christen, G.l. (1990): Influence of bovine lactoferrin on the growth of L. monocytogenes. J. Food Prot., 53: 468-472.

Revenis, M.E. and Kaliner, M.A. (1992): Lactoferrin and lysozyme deficiency in airway secretions: association with the development of broncho-pulmonary dysplasia. J. Pediatr., 121 (2): 262-70.

Sanders, J.R. and Sanders, C.C. (1997): Enterobacter spp.: pathogens poised to flourish at the turn of the century. Clinical Microbiol. Reviews, 10: 220-241.

SAS Institute (1999): User's Guide: Statistics. Version 8 Edition. SAS Inst. Inc., Cary, NC.

Simmons, B.P.; Gelfand, M.S.; Haas, M.; Metts, L. and Ferguson, J. (1989): E. sakazakii infections in neonates associated with intrinsic contamination of a powdered infant formula. Infection Control and Hospital Epidemiology, 10: 398-401.

Van Acker, J.; De Smet, F.; Muyldermans, G.; Bougatef, A.; Naessens, A. and Lauwers, S. (2001): Outbreak of necrotizing enterocolitis associated with E. sakazakii in powdered milk formula. J. Clinical Microbiol., 39: 293-297.

Weir, E. (2002): Powdered infant formula and fatal infection with E. sakazakii. Canadian Medical Association J., 166: 1570.

Yoo, M.K.; Kim, S.S. and. Oh, S. (2005): Isolation and genotyping of E. sakazakii from powdered infant formula manufactured in Korea. J. Food Sci. and Biotechnol., 14 (6): 875-877. 